\title{
Intangible Assets Disclosures in the Olive Oil Differentiation Strategy: A Theoretical Review
}

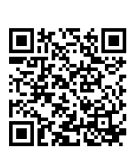

\author{
Francisca Castilla-Polo * and María Consuelo Ruiz-Rodríguez \\ Department of Financial Economy and Accounting, University of Jaén, Spain
}

Submission: January 19, 2018; Published: February 09, 2018

"Corresponding author: Francisca Castilla-Polo, Department of Financial Economy and Accounting, University of Jaén, Campus Las Lagunillas, s/n, D-3 23071 Jaen, Spain, Tel: +34-953212496; Fax: +34953218869; Email: fpolo@ujaen.es

\begin{abstract}
In an industry like olive oil mills, far from the business examples that have opted for providing information on intangible assets on a voluntary basis up until now, these disclosures can be seen as a strategic objective. Our objective is to review the state of the art in this topic in order to identify the theoretical advantages associated with its realization. The synthesis obtained in our paper highlights the role of intangible assets disclosures to reinforce the differenciation strategy. This can be applied to the specific case of the olive oil mills where their managers could consider all the advantages associated to these practices in a near future.
\end{abstract}

Keywords: Voluntary disclosures; Intangible assets; Olive oil mills; Differentiation; Strategy

\section{Introduction}

In recent years, within the literature on voluntary disclosures, studies on intangible assets have played a determining role as they provide key information for the evaluation of the competitive potential of organisations, yet in the large majority of cases they are not included within the obligatory accounting information ${ }^{1}$ [Lev [1], Wyatt \& Abernethy [2], Cañibano et al. [3]]. Intangible assets are considered to be influential in obtaining competitive advantages [Bounfour [4], Rosenberg [5], Augier \& Teece [6], Singh \& Narwal [7]] and for this reason, they constitute relevant information to be communicated by companies [Edvinsson \& Malone [8], Keong [9], Abhayawansa \& Guthrie [10], Cañibano [11]].

Until now, studies centred on intangible assets disclosures have been grouped around three lines of research. In the first place are those studies that look at the content of these types of disclosures [Brennan [12], Bozzolan et al. [13], Guthrie et al. [14], Bezhani [15], Whiting \& Woodcook [16], Nurunnabi et al. [17], and Kateb [18]]. Secondly, there are those that look into whether this information is being revealed through public and/or private channels in formats or types of reports prepared with this object in mind [Sveiby [19] and García-Meca [20]]. In a third place are those focused on why such studies are being carried out [Zambon
[21], Mouritsen et al. [22], Andriessen [23], Brüggen et al. [24], Bontis et al. [25] and Melloni [26]]. We will go on to look into some of those most relevant contributions in this area, paying special attention to the strategic effects of these disclosures manifested by the previous literature.

Specifically, we propose not only the revision of the literature on voluntary disclosures of intangible assets from a theoretical point of view, looking into whether the premises established by previous researcher are valid in their justification, but in addition we analyze its application in a specific industry, the olive oil industry, to explain why these companies should be interested in such disclosures.

We will refer these approaches to a type of company where the existence of important intangible assets [Castilla [27] and Ruiz et al. [28]] and the clear link to the area where they are established, demonstrate a high level of interest in the objectives that in our study we attribute to the voluntary disclosures of intangible assets, that of differentiation. We refer here to olive oil mill industries responsible for the production of olive oil. These are elements which characterise these companies and which at the same time support our choice as our population under study

In the first place, we are faced with an industry that has made considerable reforms in its installations in recent years together with considerable investments in technology to improve

${ }^{1}$ The accounting recognition of intangible assets can be defined as controversial. The central question of debate is if modifying the criteria of recognition in the case of intangilble assets, making demands more flexible and will permit a broadening in the range of this type of assets. 
the quality of its product. The homogenisation of material investments stimulates the need to look for intangible assets in other types of activities [Lev et al. [29]], which is the strategy of differentiation of its product. The voluntary disclosures of intangible assets should acquire more interest for this reason.

In the second place, the situation of the olive mills in production areas and the very close relation between suppliers and company, leads us to the observation that prestige is an objective of great relevance for this type of company because, amongst other factors they depend on this for their supplies. The conditions of the raw materials require that they be delivered immediately to the mill after collection, which highlights the search for and maintenance of suppliers nearby. Reputation aquires a relevant role in this sense as it allows a strengthening of the image of the olive oil mill in the area facilitating the capture and maintenance of suppliers, which in turn guarantees that the raw materials arrive in good condition to the production process. Obviously, this question is not relevant to cooperative mills in which their partners must deliver their olive production necessarily.

In the third place, the recurrent recommendations in order the oil mills address their commercialization at destination in a more intensive way. Analistas Económicos de Andalucía [30] propose that the commercial model used by these companies should promote the commercialization at destination using own brands backed by their origin, the appellations of origin protected by way of example. This idea is empirically and corroborated by Sanz \& Macías [31]. In addition, Parras [32] states that the future of this industry will necessarily involve a greater involvement of oil mills in the marketing of packaged oil. This orientation reinforces the key role of the product differentiation in this strategy given the problem of differentiation in agricultural products, raised by Castilla et al. [33], who insist on the need for differentiation via intangible attributes where reputation is a key asset in the face of the level of homogeneity of their final product, olive oil.

This paper has been structured as follows. First, we will review voluntary disclosures on intangibles assets, revising the fundamental concepts of this theoretical framework and, more especially, the relation between differentiation and these voluntary disclosures. Then, we analyze the case of the olive oil industry and its differentiation strategy. Finally, we will conclude reviewing the implications for future empirical studies in this industry.

\section{Disclosure of intangible assets: state of the art}

Halfway through the 1980s studies began to appear of a fundamentally theoretical nature that noted that the intangible assets are determinants for the results of the company with key studies like those of Wernerfelt [34], Barney [35] and Hall [36], among others. However, it was not until the early nineties that the first attempts by professionals and consultants to produce reports that measure intangible assets first appeared. It was then that the phase of real evolution began since these studies and reports on intangible assets would be used and replicated by business initiatives. In this regard it should be highlighted the important pioneer role of the Skandia AFS Company. Recent years have favoured the experimentation and development of schemes for the diffusion of these assets, the Intellectual Capital Report, and based on this we can talk of an advanced state of these practices [Dumay \& Garanina [37], Cuozzo et al. [38]].

The disclosure of intangible assets is presented as the final stage of the management of intangibles [Cañibano [11] and it has drawn attention of researchers and scholars for a relatively short time. Table 1 shows some of the most relevant studies carried out from the seminal paper of Brennan [12] to date regarding the explanation of the reasons to justify their realization.

Table 1: Some relevant papers in disclosures of intangible assets and the reasons behind.

\begin{tabular}{|c|c|c|}
\hline Authors/Year & Sample Used & Research Lines \\
\hline Lim et al. [65] & $\begin{array}{c}28 \text { biotechnology firms included in the } \\
\text { Australian Stock Exchange }\end{array}$ & $\begin{array}{c}\text { To analyze the quality in voluntary disclosures of } \\
\text { intangible assets }\end{array}$ \\
\hline Bontis et al. [25] & 34 hotels in Serbia & $\begin{array}{c}\text { To analyze the relationship between the disclosure of } \\
\text { intangible assets and the financial performance }\end{array}$ \\
\hline Melloni [26] & $\begin{array}{c}\text { 52 reports from varios sectors of Integrated } \\
\text { Reporting Emerging Practice Examples } \\
\text { Database }\end{array}$ & $\begin{array}{c}\text { To analyze the disclosure of intellectual capital in } \\
\text { Integrated Reports and their relationship in the } \\
\text { business value creation }\end{array}$ \\
\hline Singh \& Narwal [7] & $\begin{array}{c}\text { 100 best firms in the manufacturing, } \\
\text { technology and services sector in India }\end{array}$ & $\begin{array}{c}\text { To analyze the relationship between the disclosure of } \\
\text { human capital and financial and economis performance }\end{array}$ \\
\hline Abhayawansa \& Guthrie [10] & 64 reports of Australian Analyst & $\begin{array}{c}\text { To analyze the key factors in the disclosure of } \\
\text { information on intellectual capital to achieve business } \\
\text { success }\end{array}$ \\
\hline
\end{tabular}

${ }^{1}$ At the Spanish level, Andalucia provides more than $80 \%$ of the milling or production capacity of olive oil. In Jaén, it is worth pointing out that there are 335 olive oil mills. 


\section{Agricultural Research \& Technology: Open Access Journal}

\begin{tabular}{|c|c|c|}
\hline Ferchichi \& Paturel [63] & 50 listed firms on Tunisia & $\begin{array}{c}\text { To study the relationship between disclosures of } \\
\text { voluntary intellectual capital information and the } \\
\text { creation of value }\end{array}$ \\
\hline Santos \& Venancio [40] & 14 listed on Euronext enterprises & $\begin{array}{l}\text { To analyze the relationship between disclosure of } \\
\text { intangible assets and its relationship with the following } \\
\text { variables: size, industry, age and indebtednesss ratio }\end{array}$ \\
\hline Kateb [18] & 120 French listed firms & $\begin{array}{l}\text { To analyze the characteristics of the voluntary } \\
\text { disclosures of structural capital and to point out their } \\
\text { explanatory factors }\end{array}$ \\
\hline Long et al. [66] & 660 listed in Taiwan enterprises & $\begin{array}{l}\text { To corroborate the positive relationship between the } \\
\text { disclosure of human capital and performance }\end{array}$ \\
\hline Nurunnabi et al. [17] & 90 listed in Bangladesh firms & $\begin{array}{l}\text { To analyze the discloure of intangible assets in non- } \\
\text { financial firms in this country and the determining } \\
\text { structural characteristics }\end{array}$ \\
\hline Tejedo [44] & 23 listed on IBEX 35 firms & $\begin{array}{l}\text { To analyze the key factors in the disclosure of } \\
\text { intellectual capital within the scope of Corporate Social } \\
\text { Responsibility and Corporate Governance }\end{array}$ \\
\hline Vafei et al. [43] & $\begin{array}{c}220 \text { listed companies: } 63 \text { in Australia, } 49 \text { in } \\
\text { Hong Kong, } 50 \text { in Singapore and } 58 \text { in United } \\
\text { Kingdom }\end{array}$ & $\begin{array}{l}\text { To examine if the disclosure of intelectual capital in } \\
\text { listed firms is relevant in the stock martets }\end{array}$ \\
\hline Whiting \& Woodcook [16] & 70 Australian listed firms & $\begin{array}{c}\text { To identify the explaining varaibles in the discloure of } \\
\text { intangible assets }\end{array}$ \\
\hline Bezhani [15] & 30 universities in the United Kingdom & $\begin{array}{l}\text { To examine the quantity and the nature of voluntary } \\
\text { disclosure of intellectual capital in the United Kingdom } \\
\text { and the relationship between performance and } \\
\text { disclosure. }\end{array}$ \\
\hline Castelo et al. [39] & Portuguese listed companies & $\begin{array}{l}\text { To determine longitudinally the disclosure of intangible } \\
\text { assets their determining factors. }\end{array}$ \\
\hline Brüggen et al. [24] & 125 Australian listed enterprises & $\begin{array}{l}\text { To analyze the disclosure of intangible assets and their } \\
\text { determinants to keep competitive advantage in the } \\
\text { markets }\end{array}$ \\
\hline Sakakibara et al. [47] & Survey of 324 financial analysts & $\begin{array}{l}\text { To analyze the disclosure of intellectual capital and its } \\
\text { relationship to the performance of the firm }\end{array}$ \\
\hline Surroca et al. [67] & 559 enterprises from 28 different countries & $\begin{array}{l}\text { Intangible assets such as innovation, human resources, } \\
\text { reputation and organizational culture influence the } \\
\text { explanation of performance }\end{array}$ \\
\hline Hsu \& Fang [46] & 23 Taiwanese firms & $\begin{array}{l}\text { To corroborate the relationship between the disclosure } \\
\text { of intellectual capital, the learning ability of a firm and } \\
\text { the performance of the enterprise. }\end{array}$ \\
\hline Monclús et al. [45] & 8 firms of the Spanish financial market & $\begin{array}{l}\text { To study the disclosure of intangible assets and its } \\
\text { relationship with making investment decisions. }\end{array}$ \\
\hline Blaise [41] & 143 high-tech frms and 141traditional firms & $\begin{array}{l}\text { To compare the disclosure of intangible assets between } \\
\text { traditional firms and high technological content. }\end{array}$ \\
\hline Whiting \& Miller [42] & 70 listed enterprises from New Zealand & $\begin{array}{l}\text { To analyze the relationshiop between the market value, } \\
\text { book value and disclosure of intangible assets. }\end{array}$ \\
\hline Guthrie et al. [14] & 20 listed firms in Australia & $\begin{array}{l}\text { To analyze the disclosure of intangible assets in } \\
\text { Australia and Hong Kong and the role of size, industry } \\
\text { and date as determininf factors. }\end{array}$ \\
\hline Bozzolan et al. [14] & $\begin{array}{l}30 \text { non-financial firms in the Italian stock } \\
\text { excahnge in } 2001 .\end{array}$ & $\begin{array}{l}\text { To describe the quantity and the content of the } \\
\text { disclosure of intellectual capital information and the } \\
\text { factors that influence it. }\end{array}$ \\
\hline Brennan [12] & $\begin{array}{l}11 \text { listed and knowledge-intensive Irish } \\
\text { enterprises }\end{array}$ & $\begin{array}{c}\text { To analyze the disclosure of intangible assets and the } \\
\text { difference between the market value and accounting } \\
\text { value. }\end{array}$ \\
\hline
\end{tabular}


The effect of certain structural variables in the explanation of the disclosure of intangible assets results a priority in this type of papers, as can be seen in Table 1. Guthrie et al. [14], Brüggen et al. [24], Castelo et al. [39], Nurunnabi et al. [17], Kateb [18] and Santos \& Venancio [40], (among others), highlight the positive relationship between the size of the organization and these revelations. The industry effect has been analyzed by authors such as Bozzolan et al. [13] \& Blaise [41], finding the existence of divergences in the content for this reason. Finally, the positive correlation between the disclosure of intangible assets and the technology level of the company is developed by authors such as Whiting \& Woodcook [42] and, in a comparative way between intensive and non-intensive knowledge companies, by Blaise [41].

Table 1 shows that it is smaller the number of works dealing with the ultimate effect of such disclosures. The value of the disclosure of intangible assets to improve business valuation has been evidenced by Vafei et al. [43]. In addition, in the opinion of Tejedo [44], the creation of value can materialize in the company through the generation and dissemination of intangible assets and long-term wealth. There is a wide literature focused on highlighting that these disclosures are an excellent indicator of the intangible assets or total intellectual capital of an organization [Monclús et al. [25], Bontis et al. [26] and Melloni [45]] among others.

In the opinion of Abhayawansa \& Guthrie [10], the disclosure of intangible assets is of vital importance for the assessment of the organization and the determination of its relative importance in the sector in which the company operates. If an organization discloses information about its ability to innovate, its capacity to configure a stable relationship with customers and suppliers, its strong employee motivation, or the Social Responsibility that assumed, as some recognized intangible examples, this company can achieve business success through a better external assessment by its stakeholders [Hsu \& Fang [7], Sakakibara et al. [10], Abhayawansa and Guthrie [46] and Singh \& Narwal [47]].

Specifically, the improvement of the valuation offered by external users will allow companies to explain where the difference between their market value and that offered by accounting comes from. Zeghal \& Maaloul [48] analyze the economic value added as an indicator of the intangible assets and describe their impact on the stock market. In fact, the differences between market value and accounting determined the appearance of interest in intangibles in the early stages of the development of this line of research [Fombrun [49]]. Other authors who focused on explaining the disclosures of intangible assets by this reason are Brennan [12], Whiting \& Miller [16] and Vafei et al. [43].

Finally, improving corporate reputation is also presented as one of the recurring benefits when it comes to explaining the benefits of this type of disclosures [Castilla \& Gallardo [50]] and through the stakeholders [Fombrun [51]]. The insufficient recognition of intangible assets in traditional financial statements, despite their relevance to the competitive position of the firm, comes to explain this strategic advantage as far the transparency achieved through these disclosures allows reinforcing the relationship with both external and internal stakeholders.

\section{Olive oil industry need for differentiation}

Literature on this topic underlines some key advantages that could be achieved by any organization that discloses information on its intangible assets, an aspect that stands out above all in the olive oil sector given its need for differentiation, as will be explained below.

\section{The differentiation strategy in oil mills}

Oil mills are quite unknown in the field of intangibles despite the fact that, like any company, they have an intangible dimension that they must take advantage of for their own benefit. In these companies, the lack of interest in these assets is especially serious if we add the fact that investments in material goods are no longer an element on which to base their differentiation strategy.

As we have indicated, oil mills are already quite homogeneous in their infrastructure assets from some time ago [MAPA [52]]. However, this is an industry that, despite the urgent need to strengthen its commercial process in the final market, until date does not have supported the intangible investments participation in a differential and more intensive way than in tangible investments. If as a strategy of these companies, the sale of packaged oil is an immediate need to address, then the search for differential elements is a crucial aspect. In addition, differentiating an agricultural product, due to its natural properties, is more complex than in the case of industrial products [Castilla et al. [33]]. For all these reasons, intangible assets have much to say in this type of strategy as [Hall [36]] already indicated some time ago.

According to Gázquez \& Sánchez [53], the future of the sector goes through "the implementation of strategies for market differentiation and segmentation. For Parras [32], to take advantage of packaged sales versus bulk sales is a pending and necessary issue in the immediate future of this industry. Other authors in favour of the differentiation strategy are Vilar [54] who raises the need for a strategy of singularization as an incremental differentiation strategy, where this concept is understood under the following explanation "the singularization is a strategy whose purpose is to make a product different from the consumer's preferences, encouraging the latter to pay more for it, and enhancing fidelity in their consumption over time". We agree with all these recommendations for the olive oil sector, but all we underline the key role of reputation in this type of strategy as one of the most relevant advantages offered by intangible assets disclosures. There are even authors such as who consider that reputation is the goal of the management of intangibles. 


\section{Reputation as a strategy goal}

Knowing information about all the intangible assets or intellectual capital of a company will imply that its interest groups allow valuing it in a more complete way and will be useful for them as well as for the informant company itself. These intangible assets disclosures this will affect the improvement of the reputation, among other advantages that have already been explained.

It is evident that, like other companies, cooperatives in the oil sector need to manage their reputation to compete in the markets. For Gürel [55] the markets are reaching a point of saturation in which consumers increasingly evaluate more and more options and where, for this reason, the efforts that companies carry out to differentiate themselves are fundamental. In fact, reputation can be an element of differentiation and obtaining a competitive advantage that provides benefits and a balance in the context in which the activity takes place [Fombrun \& Shanley [51] and Lee \& Jungbae [56]].

Fombrun \& van Riel [57] have been found that a good reputation increases the confidence of those in the products and services the company while acting as an advertising demand in the purchase decision. In addition, Remke [58] believes that, given the current level of competition, companies should invest in reputation so that it can reach new clients. For all the above, it can be deduced that a good reputation of the oil mill can be decisive for its choice in the final market by the consumer, being reputation a vital asset for oil mills given the need for differentiation of these companies.

The effects of reputation are also related to the possibility of attracting new suppliers in the supply of olives or of maintaining existing ones, which, as indicated, was a distinctive feature of this type of industry. If suppliers can choose between different oil mills, the differentiation of those that manage their reputation in an effective way can be a key element in the decision to deliver their product.

In sum, the impact of reputation is explained by the fact that it generates favorable behaviour throught differentiation among buyers, consumers and suppliers of the company, which can lead to an increase in sales, facilitate the recruitment of suppliers and improve the perception and collaboration of interest groups. For these reasons, it can be concluded its relevance for any type of company, and, specifically for the oil mills under study which are societies with an standardizated agricultural output that need to be commercialize in the final market.

\section{The disclosures of intangible assets in the olive oil industry}

Justified the need for differentiation in these companies, we now address the role that the disclosure of intangible assets can represent in its achievement. In this sense, when a company knows specific information is expected by the community within which it is integrated and it wishes to be legitimized within that environment it will be led to give information on those aspects. Companies can suggest the voluntary disclosures of intangible assets, which offer the possibility of completing knowledge about the business assets with elements of important competitive potential, as a way greater legitimization in the sense suggested by Scott [59]. In fact, in a previous work [Castilla [60]] in an empirical approach to the olive oil sector conclude that among the olive oil mills interviewed that when divulgation is made, at a low level, the object is to improve their key intangibles, make them known and thus to seek a better situation in the market.

The knowledge of the intangible dimmension directly affects the reputation of any company, including oil mills, for this reason it is recommended that they be carried out. Figure 1 shows the logical sequence that would justify its use among the oil mills, ultimately allowing the differentiation of the same to successfully address the task of marketing olive oil directly packaged in the market. A complete knowledge of the business equity that includes all its intangible values will determine a better image, greater possibilities of attracting investments, legitimation in society, among other benefits to be taken into account. To sum up, for the previously mentioned reasons, the decision to disclose intangible assets can be of great relevance for the management of oil mills and should be considered by these companies [Chen et al. [61]].

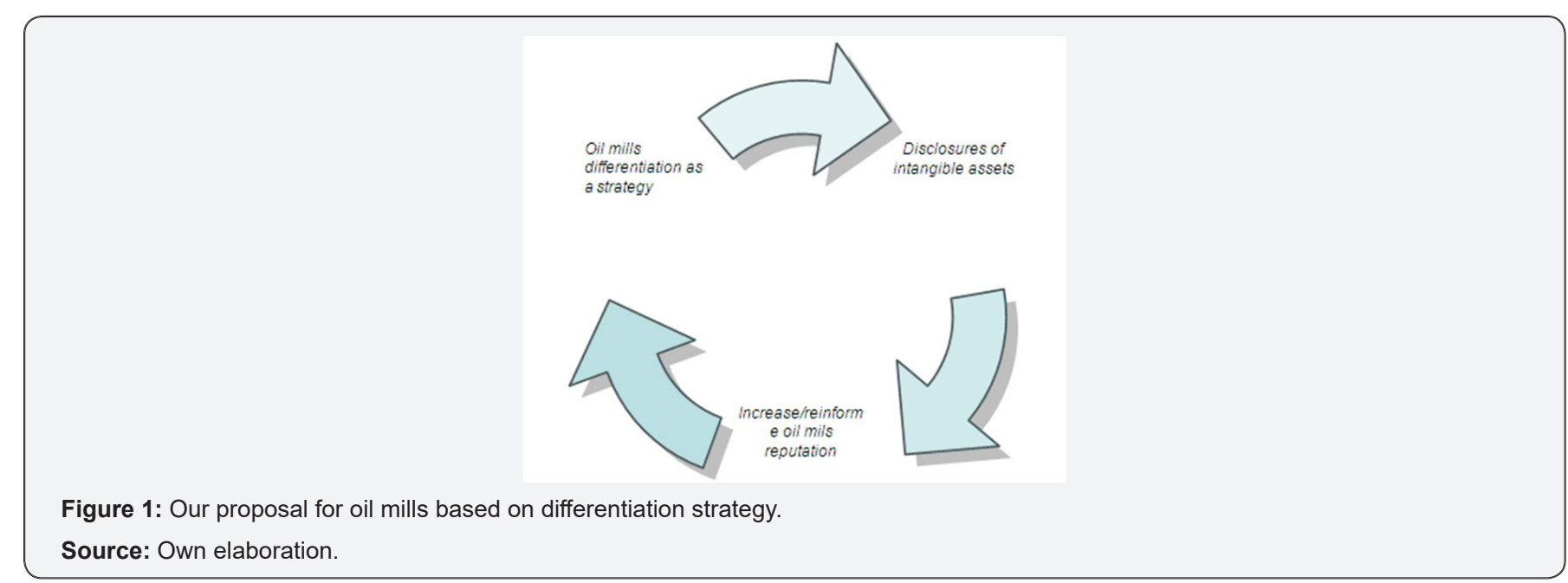


The logical order to implement the theoretical model that we propose in Figure 1 would require, as a previous step, the identification and measurement of the intangible dimension. Only if the intangibles have been valued can this information be offered to the market. We are aware of the difficulty of dealing with intangibles [Cañibano [11]], although the level of development achieved at present thanks to the use of models and guides of intangible or intellectual capital [Keong [9]] can facilitate this work that would be prior to the disclosure that we set as a basic activity for the strategic differentiation of these companies.

\section{Conclusion, Limitations and Future Lines of Research}

Our paper has offered a theoretical framework for the justification of the decision to disclose intangible assets in oil mills. Intangible assets occupy a key role in the differentiation strategy of this type of company, which, as has been noted, maintains very similar levels to material investments. Whatever the strategy of differentiation, of singulization or not, a key factor in it is the role of intangible assets in its construction, but above all a better reputation, is a fundamental goal to achieve an effective commercialization in the final market.

Our paper help contribute to the literature coming from voluntary disclosures of intangible assets in the sense that this practice can vary between industries period, Similar approaches such as the one we propose have been corroborated empirically in the pharmaceutical industry by Chen et al. [62], using the differentiation for the strategic and brand positioning of these companies, but we do not know any approach to this type of industry, which justifies the opportunity of their research.

In an industry like olive oil mills, far from the business examples that have opted for the voluntary disclosures of intangible assets up until now, differentiation should be consider by the managers of these companies as a fundamental objective, hence we encourage these companies to disclosure its intangible assets with the aim to obtain a better reputation that allow them to strategically differentiate.

Nevertheless, greater efforts are necessary to investigate further the question we have raised here on a theoretical way, specifically, it is necessary an empirical approach using a qualitative methodology to explain why or why not intangible assets disclosures should be used by these companies to reinforce their strategic positioning.

\section{References}

1. Lev B (2001) Intangibles. Management, Measurement and Reporting, Brookings Institution Press Washington DC, USA.

2. Wyatt A, Abernethy MA (2003) Accounting for intangible assets: a conceptual framework for measurement and reporting on intangible assets. Intellectual Property Research Institute of Australia.

3. Cañibano Calvo L, García Meca E, García Osma B, Gisbert Clemente A (2009) Los activos intangibles en la nueva regulación contable. AECA Madrid.
4. Bounfour A (2000) Intangible resources and competitiveness: towards a dynamic view of corporate performance. In: Buigues $P$, Jacquemin A, Marchipont JF (Eds.), Competitiveness and the value of Intangible Assets, Edward Elgar, Cheltenham, UK.

5. Rosenberg N (2004) Innovation and Economic Growth. OCDE, Paris, France.

6. Augier M, Teece D (2005) An economics perspective on Intellectual Capital. In: Marr B (Ed.), Perspectives on Intellectual Capital. Elsevier Butterworth Heinemann, Oxford, USA.

7. Singh RD, Narwal KP (2015) Intellectual capital and its consequences on company performance: a study of Indian sectors. International Journal of Learning and Intellectual Capital 12(3): 300-322.

8. Edvinsson L, Malone MS (1999) El Capital Intelectual: cómo identificar y calcular el valor de los recursos intangibles de su empresa, Gestión 2000, Barcelona.

9. Keong K (2008) Intellectual capital: definitions, categorization and reporting models. Journal of Intellectual Capital 9(4): 609-638.

10. Abhayawansa S, Guthrie J (2014) Importance of Intellectual Capital Information: A Study of Australian Analyst Reports. Australian Accounting Review 24(1): 66-83.

11. Cañibano L (2018) Accounting and intangibles. Spanish Accounting Review 21(1): 1-7.

12. Brennan N (2001) Reporting intellectual capital in annual reports: evidence from Ireland. Accounting, Auditing \& Accountability Journal 14(4): 423-436.

13. Bozzolan S, Favotto F, Ricceri F (2003) Italian annual intellectual capital disclosure: An empirical analysis. Journal of Intellectual Capital 4(4): 543-558.

14. Guthrie J, Petty R, Ricceri F (2006) The voluntary reporting of intellectual capital: Comparing evidence from Hong Kong and Australia. Journal of Intellectual Capital 7(2): 254-271.

15. Bezhani I (2010) Intellectual capital reporting at UK Universities. Journal of Intellectual Capital 11(2): 179-207.

16. Whiting RH, Miller JC (2008) Voluntary disclosure of intellectual capital in New Zealand annual reports and the 'hidden value. Journal of Human Resource Costing \& Accounting 12(1): 26-50.

17. Nurunnabi M, Hossain M, Hossain MD (2011) Intellectual Capital reporting in a South Asian country: evidence from Bangladesh. Journal of Human Resource Costing and Accounting 15(3): 196-223.

18. Kateb I (2012) An Analysis of the determinants of voluntary structural capital disclosure by Listed French Companies. International Journal of Financial Management 7(11): 95-110.

19. Sveiby K (2001) Methods for measuring intangible assets.

20. García-Meca E, Parra I, Larrán M, Martínez I (2005) The explanatory factors of intellectual capital disclosure to financial analysts. European Accounting Review 14(1): 63-94.

21. Zambon S (2003) Accounting, financial analysis and audit in the intangible economy. Final Report.

22. Mouritsen J, Bukh N, Marr B (2004) Reporting on Intellectual Capital: Why, What And How? Measuring Business Excellence 8(1): 46-54.

23. Andriessen D (2004) Making sense of Intellectual Capital. Designing a method for the valuation of intangibles. Elsevier Butterworth Heinemann, London, UK.

24. Brüggen A, Vergauwen P, Dao M (2009) Determinants of intellectual capital disclosure: evidence from Australia. Management Decision 47(2): 233-245. 
25. Bontis N, Janoševic S, Dženopoljac V (2015) Intellectual capital in Serbia's hotel industry. International Journal of Contemporary Hospitality Management 27(6): 1365-1384.

26. Melloni G (2015) Intellectual capital disclosure in integrated reporting: an impression management analysis. Journal of Intellectual Capital 16(3): 661-680.

27. Castilla (2009) La gestión de intangibles en el sector del aceite de oliva. Instituto de Estudios Giennenses, Jaén, Spain.

28. Ruiz V, Martín VM, Molina V (2012) Los intangibles del Aceite de Oliva como ventaja competitiva. Intangible Capital 8(1): 150-180.

29. Lev B, Cañibano L, Marr B (2005) An accounting perspective on Intellectual Capital. In: Marr B (Ed.), Perspectives on Intellectual Capital. Elsevier Butterworth Heinemann, Oxford, USA.

30. Analistas Económicos de Andalucía (2013) Competencia y cadena de valor en la producción y distribución del aceite de oliva en Andalucía.

31. Sanz J, Macías A (2005) Quality certification, institutions and innovation in local agro-food systems: Protected designations of origin of olive oil in Spain. Journal of Rural Studies 21(4): 475-486.

32. Parras M (2017) Las marcas de distribuidor en el mercado de los Aceites de Oliva en España y su influencia en la estrategia de orientación al mercado del sector productor. In: Vilar et al. (Eds.), El patrimonio oleícola. Análisis desde la diversidad del conocimiento. Patrimonio Oleícola, Jaén, Spain.

33. Castilla F, Gallardo D, Sánchez I, Ruiz MC (2018) An empirical approach to analyze the reputation-performance linkage in agrifood cooperatives. Journal of Cleaner Production, under review.

34. Wernerfelt B (1984) A resource-based view of the firm. Strategic Management Journal 5(2): 171-180.

35. Barney JB (1991) Firm resources and sustainable competitive advantage. Journal of Management 17(1): 99-120.

36. Hall R (1993) A framework linking intangible resources and capabilities to sustainable competitive advantage. Strategic Management Journal 14(8): 607-618.

37. Dumay J, Garanina T (2013) Intellectual capital research: a critical examination of the third stage. Journal of Intellectual Capital 14(1): 10-25.

38. Cuozzo B, Dumay J, Palmaccio M, Lombardi R (2017) Intellectual capital disclosure: a strutured literatute review. Journal of Intellectual Capital 18(1): 9-28.

39. Castelo M, Delgado CSá M, Sousa C (2010) An analysis of intellectual capital disclosure by Portuguese companies. EuroMed Journal of Business 5(3): 258-278.

40. Santos JC, Venancio MT (2013) Intellectual Capital: Information Disclosure Practices by Portuguese Companies. Revista Universo Contábil 9(2): 174-194

41. Blaise S (2008) Intellectual capital disclosure: high-tech versus traditional sector companies. Journal of Intellectual Capital 9(4): 705722

42. Whiting RH, Woodcock J (2011) Firm characteristics and intellectual capital disclosure by Australian companies. Journal of Human Resource Costing \& Accounting 15(2): 102-126.

43. Vafei A, Taylor D, Ahmed K (2011) The value relevance of intellectual capital disclosures. Journal of Intellectual Capital 12(3): 407-429.

44. Tejedo F (2011) Información divulgada del Capital Intelectual en el Marco de la Responsabilidad Social Empresarial del Gobierno Corporativo: Evolución y Factores determinantes. Tesis Doctoral, Universidad de Castilla-La Mancha, Spain.
45. Monclús Guitart R, Rodríguez Merayo A, Torres Coronas T, Vidal Blasco MA, Mateo Sanz J M (2009) Los informes de capital intelectual como medida del desempeño organizativo: Un enfoque desde el punto de vista del inversor. Comunications of the IBIMA.

46. Hsu Y, Fang W (2009) Intellectual Capital and New Product Development Performance: The Mediating Role of Organizational Learning Capability. Technological Forecasting and Social Change 76(5): 664-677.

47. Sakakibara S, Hansson B, Yosano T, Kozumi H (2010) Analysts' Perceptions of Intellectual Capital Information. Australian Accounting Review 20(3): 274-285.

48. Zeghal D, Maaloul A (2011) The accounting treatment of intangibles A critical review of the literature. Accounting Forum 35(4): 262-274.

49. Castilla F (2007) The Recent History of Intellectual Capital: the Most Significant Topics and Contexts in its Development. International Journal of Accounting, Auditing and Performance Evaluation 5( 4/5): 362-382.

50. Castilla F, Gallardo D (2016) The main topics of research on disclosures of intangible assets: a critical review. Accounting, Auditing and Accountability Journal 29(2): 323-356.

51. Fombrun CJ, Shanley M (1990) What's in a name? Reputation building and corporate strategy. The Academy of Management Journal 33(2): 233-258.

52. Ministerio de Agricultura, Pesca y Alimentación (MAPA) (2004) Diagnóstico y Análisis Estratégico del Sector Agroalimentario Español.

53. Gázquez-Abad J, Sánchez-Pérez M (2009) Factors influencing olive oil brand choice in Spain: an empirical analysis using scanner data. Agribusiness 25(1): 36-55.

54. Vilar J (2018) International Olive growing: singularization as an incremental differentiation strategy.

55. Gürel PA (2014) A strategic approach to reputation management and its reflections on sustainable competitiveness. International Journal of Research in Business and Social Sciences 3(2): 31-55.

56. Lee J, Jungbae RJ (2012) Revisiting corporate reputation and firm performance link. Benchmarking: An International Journal 19(4/5): 649-664.

57. Fombrun CJ, van Riel CBM (1997) The reputational landscape. Corporate Reputation Review 1(1/2): 5-13.

58. Remke R (2013) Corporate reputation and the discipline of organizational communication. In: Carroll C (Ed.), The handbook of communication and corporate reputation. John Willey\& Sons, New York, USA.

59. Scott WR (1992) The Organization of Environments: Network, Cultural and Historical Elements. In: Meyer JW, Scott WR (Eds.), Organizational Environments. Sage, Newbury Park, USA, pp. 155-178.

60. Castilla (2012) Divulgación voluntaria de intangibles y legitimación: la industria productora de aceite de oliva. Intangible Capital 8(3): 565600.

61. Chen M, Nguyen T, Melewar C, Dennis C (2017) Investigating the Uses of Corporate Reputation and Its Effects on Brand Segmentation, Brand Differentiation, and Brand Positioning: Evidence from the Taiwanese Pharmaceutical Industry. International Studies of Management \& Organization 47(3): 240-257.

62. Abhayawans, S, Abeysekera I (2009) Intellectual capital disclosures from sell-side analyst perspective. Journal of Intelectual Capital 10(2): 294-306.

63. Surroca J, Tribó JA, Waddock S (2010) Corporate Responsibility and Financial Performance: The role of intangible resources. Strategic Management Journal 31(5): 463-490. 
This work is licensed under Creative Commons Attribution 4.0 License DOI:10.19080/ARTOAJ.2018.14.555904
Your next submission with Juniper Publishers will reach you the below assets

- Quality Editorial service

- Swift Peer Review

- Reprints availability

- E-prints Service

- Manuscript Podcast for convenient understanding

- Global attainment for your research

- Manuscript accessibility in different formats

( Pdf, E-pub, Full Text, Audio)

- Unceasing customer service

Track the below URL for one-step submission https://juniperpublishers.com/online-submission.php 